\title{
WYBRANE DZIAŁANIA PAŃSTWOWEJ STRAŻY POŻARNEJ NA RZECZ DOSKONALENIA UKRAIŃSKICH ROZWIĄZAŃ W OBSZARZE BEZPIECZEŃSTWA POWSZECHNEGO
}

\begin{abstract}
Streszczenie: Zmieniająca się natura zagrożeń, w tym ich globalny charakter, dyktuje potrzebę ciągłej kooperacji wielu podmiotów, w tym w wymiarze międzynarodowym, które posiadają możliwość wzajemnego wspierania się. W obecnych czasach, w zmiennym i złożonym otoczeniu, organizacje, w tym pożarnicze, aby osiągnęły sukces muszą wykazać się wysoką sprawnością działania oznaczającą korzystanie z pojawiających się w otoczeniu szans. Globalizacja zagrożeń powoduje konieczność nieustannego pogłębiania współpracy międzynarodowej Państwowej Straży Pożarnej. Współpraca ta polega zarówno na wzmacnianiu współpracy dwustronnej, jak i działalności na forum organizacji międzynarodowych. W zakresie współpracy dwustronnej, oprócz współpracy z sąsiadami, jak np. z Ukrainą, rozwijane są także kontakty z innymi państwami. W Ukrainie, jak i w innych państwach Partnerstwa Wschodniego, wspiera tworzenie i rozwój jednostek straży pożarnej oraz centrów szkoleniowych, jest współorganizatorem systemów szkolnictwa specjalistycznego oraz szkolenia strażaków w zakresie ratownictwa drogowego, wodnego i chemicznego. PSP realizuje także zadania poza granicami kraju w ramach działań ratowniczych, akcji poszukiwawczo-ratowniczych i akcji humanitarnych. Jako przykład wspólnych działań ze stroną ukraińską można podać rok 2008, w którym na przełomie lipca i sierpnia na zachodzie Ukrainy miała miejsce katastrofalna powódź. W związku z dramatyczną sytuacją do wsparcia działań ratowniczych na terenie Ukrainy została wysłana Polska Grupa Ratownicza. Państwowa Straż Pożarna, w ramach międzynarodowej współpracy przyczynia się zatem do poprawy kompetencji służb ratunkowych sąsiednich państw odpowiedzialnych za reagowanie w sytuacjach zagrożenia bezpieczeństwa powszechnego.
\end{abstract}

Slowa kluczowe: bezpieczeństwo, współdziałanie, Państwowa Straż Pożarna, Ukraina.

\section{P. Соха, Університет WSB в Домброві Гурнічій}

\section{ВИБРАНІ ДІЇ ДЕРЖАВНОЇ ПОЖЕЖНОЇ СЛУЖБИ ЩОДО ПОКРАЩЕННЯ РОЗВ'ЯЗАННЯ УКРАЇНСЬКИХ РІШЕНЬ У СФЕРІ СПІЛЬНОЇ БЕЗПЕКИ}

Анотація: Змінний характер загроз, у тому числі їх глобальний характер, диктує необхідність постійної співпраці багатьох суб'єктів, у тому числі в міжнародному значенні, які мають можливість взаємної підтримки. У сьогоденні, у мінливому та складному середовищі, організації, у тому числі й пожежні, повинні демонструвати високу оперативну ефективність, щоб досягти успіху, тобто скористатися можливостями, які з'являються в навколишньому світі. Глобалізація загроз викликає необхідність постійного поглиблення міжнародного співробітництва Державної пожежної служби. Ця співпраця полягає як у зміцненні двостороннього співробітництва, так і в діяльності на форумі міжнародних організацій. У сфері двостороннього співробітництва, крім співпраці з сусідами, наприклад, з Україною, розвиваються контакти з іншими країнами. В Україні та в інших країнах Східного партнерства підтримує створення та розвиток пожежних команд та навчальних центрів, є співорганізатором систем навчання спеціалістів та підготовки пожежників у сфері дорожнього, водного та хімічного рятування. Державна пожежна служба також виконує завдання за межами країни в рамках рятувальних, пошуково-рятувальних та гуманітарних акцій. Прикладом спільних дій з українською стороною є 2008 рік, коли на межі липня- серпня на заході України сталася катастрофічна повінь. Через драматичну ситуацію на підтримку рятувальних операцій в Україні була направлена польська рятувальна група. Таким чином Державна пожежна служба в рамках міжнародного співробітництва сприяє підвищенню компетенції аварійно-рятувальних служб сусідніх країн, відповідальних за реагування в ситуаціях, що становлять спільну загрозу безпеці.

Ключові слова: безпека, співпраця, Державна пожежна служба, Україна. 


\title{
SELECTED ACTIONS BY THE STATE FIRE SERVICE OF POLAND TO IMPROVE UKRAINIAN SOLUTIONS IN THE FIELD OF JOINT SAFETY
}

\begin{abstract}
The changing nature of threats, including their global nature, dictates the need for continued cooperation of many entities, including in the international dimension, which has the possibility of mutual support. Nowadays, in a changing and complex environment, organizations, including firefighters, must demonstrate high efficiency to be successful, which means taking advantage of the opportunities that appear in the environment. The globalization of threats makes it necessary to constantly deepen the international cooperation of the State Fire Service. This cooperation consists both in strengthening bilateral cooperation and activities in the forum of international organizations. In the field of bilateral cooperation, apart from cooperation with neighbours, such as with Ukraine, contacts with other countries are also developed. In Ukraine and other Eastern Partnership countries, it supports the creation and development of fire brigades and training centres, is a co-organizer of specialist education systems and training of firefighters in the field of road, water and chemical rescue. The State Fire Service also carries out tasks outside the country as part of rescue operations, search and rescue operations and humanitarian actions. An example of joint actions with the Ukrainian side is 2008, which saw a catastrophic flood in western Ukraine in the period of July and August. Due to the dramatic situation, the Polish Rescue Group was sent to support rescue operations in Ukraine. The State Fire Service, as part of international cooperation, thus contributes to the improvement of the competencies of emergency services of neighbouring countries responsible for reacting in situations of common safety threat.
\end{abstract}

Keywords: safety, cooperation, State Fire Service, Ukraine.

Zmieniająca się natura zagrożeń, w tym ich globalny charakter, dyktuje potrzebę ciągłej kooperacji wielu podmiotów, $w$ tym $w$ wymiarze międzynarodowym, które posiadają możliwość wzajemnego wspierania się. Uwzględniając fakt, iż podstawowym motywatorem działan są potrzeby to należy przyjąć, że zaspokojenie owych potrzeb zmusza podmioty do współdziałania. Przyczyną tego jest fakt, że w otaczającej nas globalnej rzeczywistości determinowanej rodzajem i skalą zagrożeń [1] oraz ich skutkami, trudno wskazać pojedyncze formacje, które byłyby w pełni samowystarczalne i mogły samodzielnie funkcjonować i zaspokajać potrzebę bezpieczeństwa bez odwoływania się do współdziałania z innymi podmiotami, w tym z innych państw. Stąd też współdziałanie, współpraca czy wzajemne wspieranie się są wszechobecne w międzynarodowych stosunkach, a rozwój współczesnych społeczeństw jest ściśle związany ze wzrostem wzajemnych zależności [2].

Działania mające na celu zapewnienie bezpieczeństwa „układają się zwykle w pewien dość skomplikowany system z zależnymi od siebie podsystemami” [3]. Daje to z kolei możliwość wyróżnienia wielu wymiarów i płaszczyzn bezpieczeństwa [4], w tym kluczowe z punktu widzenia problematyki badań [5], bezpieczeństwo powszechne, rozumiane jako stan zapewniający ochronę życia i zdrowia obywateli oraz majątku narodowego przed skutkami klęsk żywiołowych, czyli ekstremalnymi zjawiskami powodującymi znaczne szkody na terenie objętym tym zjawiskiem, pozostawiającymi po sobie często zmieniony obraz powierzchni ziemi.
W obecnych czasach, w zmiennym i złożonym otoczeniu, organizacje, w tym pożarnicze, aby osiągnęły sukces muszą wykazać się wysoką sprawnością działania oznaczającą korzystanie z pojawiających się w otoczeniu szans [6]. Sprawność działania oznacza zatem zdolność radzenia sobie ze zmianami, tworzenie relacji $\mathrm{z}$ partnerami zewnętrznymi zamiast dążenia do zachowania stabilności. [7] Globalizacja zagrożeń powoduje konieczność nieustannego pogłębiania współpracy [8] międzynarodowej Państwowej Straży Pożarnej. Współpraca ta polega zarówno na wzmacnianiu współpracy dwustronnej, jak i działalności na forum organizacji międzynarodowych podejmujących problematykę pożarnictwa, ratownictwa, ochrony ludności, przeciwdziałania klęskom żywiołowym i awariom technologicznym oraz ich skutkom. W zakresie współpracy dwustronnej oprócz współpracy z sąsiadami rozwijane są także kontakty z innymi państwami. Biuro Współpracy Międzynarodowej Komendy Głównej Państwowej Straży Pożarnej inicjuje, planuje i prowadzi sprawy związane ze współpracą w ramach Unii Europejskiej oraz współpracą międzynarodową w zakresie kompetencji Komendanta Głównego Państwowej Straży Pożarnej. Koordynuje współpracę dwustronną oraz wielostronną, $\mathrm{w}$ tym współpracę $\mathrm{z}$ organizacjami międzynarodowymi działającymi w dziedzinie ochrony przeciwpożarowej, ratownictwa, ochrony ludności i obrony cywilnej, a także współpracę międzynarodową prowadzoną przez jednostki organizacyjne PSP. Biuro uczestniczy w procesie pozyskiwania i wykorzystania przez PSP środków pochodzących z funduszy europejskich. Organizuje i monitoruje działania jednostek organizacyjnych PSP oraz 
komórek organizacyjnych Komendy Głównej PSP w tym zakresie, koordynuje opracowywanie wniosków o dofinansowanie projektów ze środków pochodzących $\mathrm{z}$ funduszy europejskich oraz realizuje przedmiotowe projekty." [9]

Współdziałanie jest jednym z podstawowych procesów kształtujących rzeczywistość. [10] Prowadzi ono do tworzenia się różnych więzi wśród osób, grup, jak również rodzi ich poczucie tożsamości z danym zespołem, co zapewnia trwanie i sprawne funkcjonowanie tego zespołu na rzecz osiągnięcia wspólnych celów jej członków [11]. Świadomość współdziałania stanowi zatem bardzo ważny element [12]. Ma ona miejsce wtedy, kiedy współdziałający wie, iż nawiązał kontakt z inną osobą. Nie zawsze jest to kontakt tylko z jedną osobą, najczęściej jest to grupa osób, połączona ze sobą poprzez:

-wspólne dążenie do osiągnięcia założonego celu lub wykonanie określonego zadania poprzez wypracowany przez grupę system działania;

-względnie podobny i spójny system wartości, które pełnią rolę wyznaczników i regulatorów celów oraz dążeń człowieka. Ukształtowanie hierarchii podobnych wartości grupy czy zespołu jest niezbędne do podejmowania odpowiedzialnych decyzji [13]. J. Szczepański uznaje za wartość dowolny przedmiot materialny lub idealny, ideę lub instytucję, przedmiot rzeczywisty lub wyimaginowany, w stosunku do którego jednostki lub zbiorowość przyjmują postawę szacunku, przypisując mu ważną rolę $\mathrm{w}$ swoim życiu, a dążenie do jego osiągnięcia odczuwają jako swoisty przymus [14].

Wg J. Prońko cel współpracy ustala się według ustalonych zasad. Zasady te powinny być dokładnie określone i zrozumiałe dla instytucji współpracujących, a są to m.in.: szczegółowość; realność aktualnych możliwości; określenie czasu trwania zaplanowanego przedsięwzięcia, jak również jego akceptacja przez zaangażowane instytucje [15].

Tworzenie sprawnie funkcjonującego i efektywnie współpracującego zespołu jest rzeczą niezmiernie trudną, czasochłonną i wymagającą znacznego wysiłku i zaangażowania wszystkich zainteresowanych osób. $Z$ tego też względu często to, co nazywamy współpracą sprowadza się do sekwencyjnej realizacji ustawowych zadań przez poszczególne instytucje [16].

Po ustaleniu zasadniczych celów oraz sposobu ich realizacji, ważnym elementem jest stworzenie planu przyszłych działań pomiędzy podmiotami, które współpracują ze sobą. Harmonogram można zaliczyć do podstawowych narządzi ułatwiających koordynację tych działań [17]. Jest to nic innego jak określenie celu głównego i celów szczegółowych, dokładne rozplanowanie przebiegu czynności w czasie oraz wskazanie ich kolejności wykonywania. Istotne jest również określenie przewidywanego i oczekiwanego czasu trwania zaplanowanych zadań, czyli określenie ich początku oraz końca [18]. ,[...] We współczesnym świecie wszyscy znajdują się w globalnym systemie, a w związku z tym wszyscy są od siebie zależni. Paradygmatem organizacji jest człowiek, cel i struktura. Inspiracją do działania człowieka rozumianego jako jednolity organizm o cechach fizycznych, biologicznych i społecznych są motywacje wynikające $\mathrm{z}$ konieczności zaspokojenia potrzeb zewnętrznych i wewnętrznych. Podmiotem współdziałania jest człowiek reprezentujący niezależną organizację. Czynniki fizyczne, biologiczne i społeczne stanowią swoisty system kooperacji, jeżeli któryś z czynników przestaje funkcjonować, to możemy powiedzieć, że coś ogranicza system. Utrudnienia w funkcjonowaniu systemu kooperacji stanowią barierę $\mathrm{w}$ realizacji naszych dążeń, są przeszkodą $\mathrm{w}$ osiąganiu zamierzonych celów. Wyróżnienie i zdefiniowanie tych właśnie ograniczeń jest podstawowym bodźcem początkującym proces współdziałania, punktem wyjścia do poszukiwania możliwości ich przezwyciężenia poprzez wspólne działanie z jednostkami (elementami), które potrafią pokonać określone bariery" [19]. Można uznać, że do współdziałania dochodzi wówczas, gdy wyróżniono ograniczenia stanowiące barierę $\mathrm{W}$ realizacji naszych zadań, których nie można przezwyciężyć działaniem osobistym (jednostkowym) oraz kiedy zostaje uświadomiona potrzeba wspólnego działania $\mathrm{z}$ innymi dla pokonania ograniczeń i osiągnięcia zamierzonego celu [20]. „[...] W związku tym możemy wyróżnić dwie ogólne sytuacje, w których nie dochodzi lub dochodzi do wspólnego działania. Pierwsza, gdy nie rozpoznano możliwości współdziałania, ponieważ wyróżnione ograniczenia możemy przezwyciężyć działaniem osobistym. Druga, gdy stwierdzono możliwość współdziałania poprzez wyróżnienie ograniczeń i stwierdzenie potrzeby wspólnego działania dla ich pokonania w imię celu nadrzędnego. W pierwszym przypadku cel współdziałania zanika, natomiast $\mathrm{w}$ drugim jest rozwijany $\mathrm{w}$ dalszych działaniach. Dlatego też możemy stwierdzić, że wspólny cel jest tym, co ukierunkowuje działania i jednoczy jego realizatorów. Jednakże należy zaznaczyć, że każdy wspólny cel ma dla współdziałającej strony dwa aspekty: subiektywny i kooperacyjny. Cel subiektywny dotyczy bilansu nakładów i korzyści, cel kooperacyjny tak długo zaś jest postrzegany, jak długo cel jest pewnym aktem współdziałania. Z chwilą osiągnięcia swych celów przez podmioty współdziałające, potrzeba współdziałania zanika" [21]. Współpraca i współdziałanie nie posiadają zdefiniowanego rozróżnienia, dlatego przeważnie 
używa się ich zamiennie (jako synonimy). Pomimo tego, autorzy literatury przedmiotu często definiują współpracę jako jedną $\mathrm{z}$ form, element szerszego pojęcia jakim jest współdziałanie [22].

Od wielu lat Państwowa Straż Pożarna w Polsce jest zaangażowana $\mathrm{w}$ międzynarodowe działania rozwojowe i pomocowe. Na Ukrainie, jak i w innych państwach Partnerstwa Wschodniego, wspiera tworzenie i rozwój jednostek straży pożarnej oraz centrów szkoleniowych, jest współorganizatorem systemów szkolnictwa specjalistycznego, poprzez organizację szkolenia kształcącego kadrę trenerską przyszłych strażaków oraz szkolenia strażaków w zakresie ratownictwa drogowego, wodnego i chemicznego. Ponadto funkcjonariusze PSP promują wolontariat pożarniczy wśród młodzieży, poprzez pomoc $\mathrm{w}$ organizowaniu jednostek ochotniczej straży pożarnej. Podejmowane działania mają na celu wsparcie strażakom różnych państw w poprawie jakości systemu kształcenia ratowników i zarządzania w służbie pożarniczej. Przykładów podejmowanych działań na rzecz współpracy polskiej PSP $\mathrm{z}$ odpowiednikami naszych sąsiadów, w tym na Ukrainie można przytoczyć wiele. W dalszej części zostaną przedstawione założenia i efekty współpracy PSP $z$ Ukrainą na przykładzie zrealizowanego projektu pod nazwą ,Zasady organizacji dekontaminacji całkowitej wynikające z zagrożeń chemiczno - ekologicznych przy zdarzeniach masowych". Ponadto zostaną przedstawione wybrane działania podejmowane $\mathrm{w}$ latach 2014-2020, w tym w związku z pandemią wywołaną koronawirusem Sars-Cov2, wywołującym chorobę zakaźną ludzi Covid-19.

W ramach Wieloletniego Programu Współpracy Rozwojowej na lata 2012 - 2015 wdrażanego przez Ministerstwa Spraw Zagranicznych Centralna Szkoła Państwowej Straży Pożarnej realizowała projekt pt. „Zasady organizacji dekontaminacji całkowitej wynikające z zagrożeń chemiczno - ekologicznych przy zdarzeniach masowych". Projekt był realizowany w dwóch modułach, w których zostało przeszkolonych po 20 przedstawicieli ukraińskiej straży pożarnej $\mathrm{Z}$ Lwowskiego Uniwersytetu Bezpieczeństwa i Ochrony Życia. Zaznaczyć należy, że projekt był kontynuacją zapoczątkowanej w roku 2010 współpracy w ramach której przeszkolono po 30 ratowników z Ukrainy i Gruzji w zakresie ratownictwa technicznego. Projekt przyczynił się do wzrostu kompetencji służb publicznych Ukrainy, jednocześnie wpływając na podniesienie sprawności wykonywanych zadań i poprawę bezpieczeństwa [23] oraz stanu środowiska naturalnego. Zajęcia były realizowane na poligonie szkolnym, w nowoczesnych salach wykładowych oraz pracowniach praktycznych i laboratoriach. Zakres tematyczny szkolenia obejmował między innymi: zagrożenia chemiczne w czasie imprez masowych, rozpoznawanie zagrożeń - oznakowanie niebezpiecznych materiałów chemicznych $\mathrm{w}$ transporcie, magazynowaniu $\mathrm{i}$ obrocie, taktykę $\mathrm{w}$ ratownictwie chemicznym, organizację dekontaminacji wstępnej w KSRG i dekontaminacji ostatecznej, etc. Ratownicy z Lwowskiego Państwowego Uniwersytetu Bezpieczeństwa i Ochrony Życia otrzymali ponadto wyposażenie $\mathrm{w}$ postaci, m.in.: pneumatycznego zestawu ratowniczego, zestawu hydraulicznego do ratownictwa technicznego oraz zestawu dekontaminacyjnego. Uczestnicy szkolenia zapoznania się również z funkcjonowaniem chemicznej jednostki ratowniczo gaśniczej w Katowicach - Piotrowicach oraz organizacją bezpieczeństwa na Stadionie Miejskim we Wrocławiu, który był jedną z aren Turnieju Finałowego Mistrzostw Europy w Piłce Nożnej UEFA EURO 2012. Podkreślić warto, że wiedza nabyta w czasie szkolenia została następnie przekazana strażakom $\mathrm{z}$ jednostek terenowych [24].

Polsko-ukraińska współpraca to również efekt Planu Współpracy Państwowej Straży Pożarnej i Państwowej Służby Ukrainy ds. Sytuacji Nadzwyczajnych na lata 2014-2016 [25] podpisanego przez gen. brygadiera Wiesława Leśniakiewicza - komendanta głównego Państwowej Straży Pożarnej i płk Siergieja Boczkowskiego - szefa Państwowej Służby Ukrainy ds. Sytuacji Nadzwyczajnych. Dokument przewidywał, m.in. organizację wspólnych przedsięwzięć, co umożliwiło stronie ukraińskiej zapoznanie się ze strukturą jednostek ochotniczych straży pożarnych (OSP) oraz wymianę doświadczeń w zakresie współpracy OSP z innymi organizacjami pozarządowymi. Pod koniec 2014 roku przeprowadzono pierwsze szkolenia $\mathrm{z}$ zakresu ratownictwa medycznego, w których wzięło udział 119 uczestników z obwodów donieckiego, ługańskiego, chmielnickiego, tarnopolskiego, zaporoskiego, lwowskiego, iwanofrankiwskiego, chersońskiego, a także przedstawiciele Lwowskiego Uniwersytetu Bezpieczeństwa i Ochrony Życia. Współpraca polsko-ukraińska sprowadzała się również do odbywania praktyk przez studentów Lwowskiego Uniwersytetu oraz strażaków Państwowej Służby Ukrainy (PSU) w szkołach i jednostkach organizacyjnych Państwowej Straży Pożarnej [26].

W latach 2019 - 2020 r. w działania na rzecz międzynarodowej współpracy angażowały się m.in. Szkoła Główna Służby Pożarniczej w Warszawie (SGSP) oraz Komenda Wojewódzka PSP w Krakowie. W podanym okresie Szkoła Główna Służby Pożarniczej realizowała dodatkowo współpracę z Gruzją. W obu państwach SGSP wzięła udział w tworzeniu regionalnych centrów ratowniczych. Efektem podejmowanych działań była, m.in. budowa wielomodułowych trenażery kontenerowych, zakup sprzętu ochrony indywidulanej i specjalistycznego 
wyposażenia. Przeszkolono dodatkowo kadrę instruktorską oraz przygotowano, a następnie wdrożono program szkolenia instruktorów praktycznej nauki zawodu.

Komenda Wojewódzka PSP w Krakowie na Ukrainie prowadziła $\mathrm{z}$ kolei działania szkoleniowe w obszarze ratownictwa techniczno-drogowego i pożarów wewnętrznych. Przekazała jednocześnie stronie ukraińskiej sprzęt niezbędny do prowadzenia szkoleń, w tym środki ochrony indywidualnej, hydrauliczne narzędzia ratownicze. W związku z pandemią, wywołaną koronawirusem Sars-Cov2, wywołującym chorobę zakaźną ludzi Covid-19 przekazano dodatkowo cztery namioty wraz z wyposażeniem, na potrzeby polowych izb przyjęć lub obiektów przeznaczonych do dekontaminacji i fumigacji skażonych osób i sprzętu oraz cztery, tzw. zamgławiacze termiczne, tj. specjalistyczne urządzenia dezynfekujące. [27]

Podejmując kwestie międzynarodowej współpracy PSP, wskazać należy, że w 2020 roku, w związku z pandemią, Państwowa Straż Pożarna zaangażowała się również w międzynarodowe akcje pomocowe na rzecz: Białorusi, Mołdawii oraz krajów bałkańskich, tj.: Albanii, Bośnii i Hercegowiny, Czarnogóry, Kosowa, Macedonii Północnej i Serbii, poprzez zapewnienie transportu pomocy humanitarnej zawierającego maseczki medyczne i ochronne, płyn dezynfekujący, fartuchy i kombinezony, przyłbice oraz respiratory i leki. Zaznaczyć również należy, że PSP realizuje zadania poza granicami kraju w ramach działań ratowniczych [28], akcjach poszukiwawczoratowniczych i akcjach humanitarnych. Jako przykład wspólnych działań ze stroną ukraińską można podać rok 2008, w którym na przełomie lipca i sierpnia na zachodzie Ukrainy miała miejsce katastrofalna powódź. W związku z dramatyczną sytuacją do wsparcia działań ratowniczych na terenie Ukrainy została wysłana Polska Grupa Ratownicza UKRAINA 2008, skład w której weszły dwie kompanie powodziowe MAZOWSZE i KATOWICE oraz zastęp kwatermistrzowski LUBLIN. W sumie 78 ratowników, 31 samochodów, 9 przyczep, 4 łodzie płaskodenne, 8 pomp dużej wydajności oraz 17 pomp szlamowych - małej i średniej wydajności. Polska Grupa Ratownicza rozpoczęła działania ratownicze 4 sierpnia. Działania, polegające głównie na wypompowywaniu wody z zalanych obiektów i terenów, prowadzono w następujących miejscowościach: Borszcziv, Prutivka, Zabołotów, Tułukiv, Śniatyń, Budiliw, Widiniv, Ilinci. Strażacy prowadzili również akcje humanitarne, dowożąc wodę pitną poszkodowanym mieszkańcom rejonu powodzi oraz przeprowadzając dezynfekcje studni. Podczas 6 dni akcji ratowniczej Polska Grupa Ratownicza przeprowadziła 1665 interwencji, co spotkało się z uznaniem Ukraińców oraz przedstawicieli Monitoring and Information Center Unii Europejskiej. [29]
Państwowa Straż Pożarna, w ramach międzynarodowej współpracy, dzieląc się specjalistyczną wiedzą, wspiera systemy szkolnictwa specjalistycznego innych państw, zwłaszcza na Ukrainie i w pozostałych krajach Partnerstwa Wschodniego, jednocześnie wyposażając je w odpowiedni sprzęt, czym przyczynia się do poprawy kompetencji służb ratunkowych sąsiednich państw odpowiedzialnych za reagowanie $\mathrm{w}$ sytuacjach zagrożenia bezpieczeństwa powszechnego. Podkreślić przy tym trzeba, że udział PSP w projektach międzynarodowych posiada szczególne znaczenie dla zacieśnienia współpracy międzynarodowej dotyczącej tak ważnej dziedziny, jaką jest doskonalenie działania służb ratowniczych na rzecz realizacji zadań w warunkach zagrożenia bezpieczeństwa powszechnego.

\section{Bibliografia:}

1. B. Wiśniewski, Praktyczne aspekty badań bezpieczeństwa, Difin, Warszawa 2020, s. 15-28.

2. J. Prońko, Teoretyczne aspekty współdziałania, [w:] red. E. Nowak i B. Wiśniewski, Współdziałanie struktur organizacyjnych resortu spraw wewnętrznych $i$ administracji z pozostatymi elementami systemu obronnego, MSWiA, Warszawa 2006, s. 46.

3. J. Kaczmarek, A. Skowroński, Bezpieczeństwo. Świat-Europa-Polska, Alta 2, Wrocław 1998, s. 5.

4. Szerzej, K. Jałoszyński, B. Wiśniewski, T. Wojtuszek (red. nauk.), Współczesne postrzeganie bezpieczeństwa, WSA, Bielsko-Biała 2007.

5. Szerzej, A. Czupryński, B. Wiśniewski, J. Zboina (red. nauk.), Nauki o bezpieczeństwie. Wybrane problemy badań, Centrum NaukowoBadawcze Ochrony Przeciwpożarowej im. Józefa Tuliszkowskiego Państwowy Instytut Badawczy, Józefów 2017 oraz B. Wiśniewski (red. nauk.), Bezpieczeństwo $w$ teorii $i$ badaniach naukowych, WSPol, Szczytno 2011.

6. R. Gwardyński, Wybrane problemy działań prewencyjnych Policji, ,Zeszyty Naukowe SGSP” Nr 74/2/2020, Szkoła Główna Służby Pożarniczej, Warszawa 2020, s. 302.

7. T. Kotarbiński, Traktat o dobrej robocie, Ossolineum, Wrocław - Warszawa - Kraków Gdańsk 1973, s. 352.

8. Szerzej, R. Jakubczak, B. Wiśniewski (red. nauk.), Wyzwania, szanse, zagrożenia i ryzyko dla bezpieczeństwa narodowego RP o charakterze wewnętrznym, WSPol, Szczytno 2016. 3241

9.http://www.straz.gov.pl/page/index.php?str=

10. J. Kozioł, Wspótdziałanie, [w:] red. nauk. B. Wiśniewski, Kierunki i obszary współdziałania policji Rzeczypospolitej Polskiej oraz Republiki Czeskiej w sytuacjach nadzwyczajnych zagrożén dla ludzi i środowiska, Bielsko-Biała - Karvina 2011, s. 56. 
11. Wspótdziałanie administracji wojskowej z administracja cywilna i podmiotami gospodarczymi $w$ realizacji zadań $z$ zakresu bezpieczeństwa narodowego (wybrane problemy), red. R.Szynowski, TWO, Warszawa 2008, s. 6.

12. Szerzej, A. Czupryński, B. Wiśniewski, J. Zboina (red. nauk.), Bezpieczeństwo. Teoria - Badania - Praktyka, CNBOP - PIB, Józefów 2015, s. 21 22.

13. B. Wiśniewski, R. Kowalski, J. Kozioł, M Szyłkowska, Bezpieczeństwo procesów decyzyjnych, Wrocław 2018, s. 5.

14. Zob. J. Szczepański, Elementarne pojęcia socjologii, Warszawa 1970.

15. J. Prońko, Wspótpraca w obszarze bezpieczeństwa, [w:] red. K Jałoszyński, B. Wiśniewski, T. Wojtuszek, Wspótczesne postrzeganie bezpieczeństwa, WSA, Bielsko-Biała 2007, s. 30.

16. J. Prońko, Teoretyczne aspekty wspótpracy, [w:] red. nauk. J. Kręcikij, B. Wiśniewski, G. Abgarowicz, Wspótpraca cywilno-wojskowa $w$ zarzadzaniu kryzysowym, Warszawa 2007, s. 19.

17. J. Prońko, Współpraca w obszarze..., s.30.

18. Tamże.

19. Wspótdziatanie administracji wojskowej $z$ administracja cywilna $i$ podmiotami gospodarczymi $w$ realizacji zadań $z$ zakresu bezpieczeństwa narodowego (wybrane problemy), red. R. Szynowski, TWO, Warszawa 2008, s. 6.

20. Ch. I. Barnard, Funkcje kierownicze, Wydawnictwo Nowoczesność, Kraków 1997, s. 164.

21. Wspótdziałanie administracji wojskowej, s. 6.

22. J. Polak, Wspótpraca i wspótdziatanie międzyorganizacyjne w telekomunikacji mobilnej, "Studia Ekonomiczne" 2016, nr 299, s. 284-287.
23.Szerzej, B. Kaczmarczyk, B. Wiśniewski, R. Gwardyński, Security of an individual, Zeszyty Naukowe Państwowej Wyższej Szkoły Zawodowej im. Witelona w Legnicy Nr 3 (28)/2018, s. $67-78$.

24. https://www.cspsp.pl/index.php/pl/23-polska-pomoc

25.https://archiwum.mswia.gov.pl/p1/aktualno sci/13018,Szkolenia-dla-ukrainskich-strazakow.html 26. Tamże.

27. Działania polskich strażaków dla lokalnych społeczności w krajach Polskiej pomocy na: https://www.gov.pl/web/polskapomoc/dzialania-polskich-strazakow-dla-lokalnych-spolecznosci-w-krajach-polskiej-pomocy

28. B. Kogut, P. Lubiewski, Management and coordination of rescue activities, Вісник Львівського Державного Університету Безпеки Життєдіяльності, Nr 17, Львів 2018, s. 68-73.

29. A. Krzemińska, Państwowa Straż Pożarna $w$ działaniach poza granicami kraju, „Obronność” Zeszyty Naukowe” 2016, nr 3(19), s. 126-127.

\section{* Оглядова стаття}

Стаття надійшла до редакції 01.12.2021. 